\title{
Inflammatory cells and pancreatic tumor progression
}

\section{Komórki nacieku zapalnego a rozwój raka trzustki}

\author{
Katarzyna Gardian¹, Marek Durlik ${ }^{12}$ \\ 1Department of Surgical Research and Transplantology, Mossakowski Medical Research Centre, Polish Academy of Sciences, \\ Warsaw, Poland \\ 2Department of Gastroenterology and Transplantology Surgery, Central Clinical Hospital of the Ministry of Internal Affairs, \\ Warsaw, Poland
}

Prz Gastroenterol 2013; 8 (2): 133-137

DOI: $10.5114 / p g .2013 .34840$

Key words: pancreatic cancer, macrophages, neutrophils, microenvironment.

Słowa kluczowe: rak trzustki, makrofagi, neutrofile, mikrośrodowisko.

Address for correspondence: Katarzyna Gardian, Department of Surgical Research and Transplantology, Mossakowski Medical Research Centre, Polish Academy of Sciences, 5 Pawinskiego St, 02-106 Warsaw, Poland, phone: +48 2260865 21, fax: +48 226685334 , e-mail: kgardian@gmail.com

\begin{abstract}
Introduction: Pancreatic adenocarcinoma remains one of the deadliest cancers. Many years of research have improved neither treatment nor diagnosis of this devastating disease. Infiltrating inflammatory cells might be part of the antitumor response but also they may take part in supporting tumor invasion. In particular, macrophages and neutrophils were shown to present pro-tumor phenotype.

Aim: To define the inflammatory microenvironment within the pancreatic tumor and how it influences tumor progression and the ability to create metastases.

Material and methods: Pancreatic tumor tissue samples were collected from 36 patients diagnosed with pancreatic cancer. Tumor tissue was analyzed using immunohistochemistry. Staining against CD68, CD3, CD56 and neutrophil elastase was performed and evaluated using Microlmage software. Results: We observed numerous infiltrates of lymphocytes and macrophages. Neutrophils were also present but no NK cells were observed. Inflammatory cells were present around neoplastic glands and also strongly around nerves infiltrated by cancer cells. We found that the number of infiltrating macrophages was significantly higher in the group of patients with lymph node metastases and in tumors with perineural invasion.

Conclusions: There is no doubt that infiltrating tumor cells are a pivotal element of the pancreatic tumor microenvironment. In particular, macrophages take part in tumor progression and enable creation of metastases. Investigating infiltrating macrophages might be useful in evaluating the possibility of metastases occurrence.
\end{abstract}

\section{Streszczenie}

Wstęp: Rak trzustki jest jednym z nowotworów o największej śmiertelności. Prowadzone przez wiele lat badania nie udoskonality dotychczas metod leczenia ani metod diagnostycznych. W ostatnich latach zwrócono uwagę na mikrośrodowisko raka trzustki i jego udział $w$ procesie rozwoju guza i przerzutowania. Komórki nacieku zapalnego, wchodzące w skład mikrośrodowiska, mogą być częścią odpowiedzi przeciwnowotworowej, ale mogą także wspierać rozwój guza. Stwierdzono, że makrofagi i neutrofile wykazują fenotyp wspierający rozwój guza.

Cel: Określenie komórek nacieku zapalnego występujących w tkance guza trzustki oraz ich wpływu na rozwój guza trzustki. Materiat i metody: Fragmenty guzów trzustki pobrano od 36 pacjentów poddanych resekcji trzustki ze względu na raka trzustki. Tkanki guza przeanalizowano za pomocą immunohistochemii, wykonano barwienia przeciwko CD3 (limfocyty), CD68 (makrofagi), elastazie (neutrofile) i CD56 (komórki NK). Oceny barwień dokonano przy użyciu programu Microlmage. Wyniki: Zaobserwowano liczne nacieki makrofagów i limfocytów. W tkance guza były również obecne neutrofile, natomiast nie stwierdzono komórek NK. Nacieki były zlokalizowane wokół ognisk nowotworowych. Analiza wykazała, że nacieki makrofagów były liczniejsze w przypadku występowania przerzutów do węzłów chłonnych, a także w przypadku naciekania nerwów przez komórki nowotworowe $(p=0,0113)$. Wnioski: Komórki nacieku zapalnego są istotnym elementem mikrośrodowiska raka trzustki, zwłaszcza makrofagi uczestniczą w rozwoju guza i przerzutowania. Znajomość liczby naciekających makrofagów jest użyteczna w ocenie możliwości występowania przerzutów w raku trzustki. 


\section{Introduction}

In spite of intensive research during many years, pancreatic adenocarcinoma remains one of the deadliest cancers. In Poland, mortality from pancreatic cancer increased by $30 \%$ during the last ten years [1]. Surgical intervention remains the main possibility of treatment but it is still burdened with many complications. Chemotherapy and radiotherapy, though constantly being improved, do not have a significant impact on long-term survival [2].

During many years of research many facts about this devastating disease have been established. Genetic changes in pancreatic cancer cells have been well characterized and soon it became clear that also microenvironmental factors contribute to the spread of disease. One of these factors are infiltrating inflammatory cells; they might be part of the antitumor response but they also may take part in supporting tumor invasion [3].

Macrophages have been most widely described as associated with tumor progression. Two main types of macrophages have been recognized. M1 activation is associated with anti-tumor reactivity. This type of macrophage is activated by toll-like receptor ligands and interferon $\gamma$. They produce pro-inflammatory cytokines and nitric oxide. M2 macrophages have immune suppressive and wound healing properties. Their activation is stimulated by interleukin 4 and 13 (IL-4 and IL-13). These are the two main ways of activation although macrophage plasticity leads to a variety of activation types.

Tumor-associated macrophages exhibit M2 polarization mostly. They are a source of angiogenic factors (VEGF, ANG1 and ANG2) and proteases: urokinase-type plasminogen activator (UPA) and matrix metalloproteinases (MMP). In this way they contribute to angiogenesis and cell detachment leading to tumor progression and metastases [4].

Recently also the role of neutrophils in the tumor microenvironment has been studied [5]. Also in this case it was claimed that under microenvironmental influence neutrophils might exhibit a protumor phenotype. Similarly N1 and N2 phenotypes were described and N2 phenotype may contribute to tumor progression. The acquisition of a malignant phenotype of neutrophils is driven by tumour growth factor $\beta$ (TGF- $\beta$ ), and its inhibition was associated with re-polarization to N1 phenotype [6]. What is more, neutrophil-derived elastase was reported to take part in tumor promoting activity. High levels of elastase were correlated with poor prognosis in breast and lung cancer $[7,8]$.

Based on this information, in our study we wanted to define the inflammatory microenvironment within pancreatic tumor, how it influences tumor progression and the ability to create metastases.

\section{Material and methods}

\section{Patients and specimen collection}

Pancreatic tumor tissue samples were collected from 36 patients who underwent surgical resection due to pancreatic cancer at the Clinical Department of Gastroenterology Surgery and Transplantation, Central Clinical Hospital, Ministry of Interior in Warsaw. The study group consisted of 14 women and 22 men; mean age was 66 years (48-85 years).

Tissues were collected based on a protocol approved by the Bioethics Committee of Central Clinical Hospital, Ministry of Interior in Warsaw. Tumors were classified according to TNM staging and tumor grade by means of routine methods.

For protein isolation, the samples were frozen and stored at $-20^{\circ} \mathrm{C}$ until they were used. Samples for immunohistochemical analysis with dimensions of $5 \mathrm{~mm}$ $\times 5 \mathrm{~mm} \times 5 \mathrm{~mm}$ were frozen for $45 \mathrm{~s}$ in acetone using dry ice at a temperature of $-70^{\circ} \mathrm{C}$ and stored at $-80^{\circ} \mathrm{C}$

\section{Immunohistochemistry}

Frozen tissue from pancreatic cancer was cryocut into $5 \mu \mathrm{m}$ sections. Each tissue was stained with hematoxylin-eosin (H\&E). The Dako REAL ${ }^{\mathrm{TM}}$ EnVision $^{\mathrm{TM}}$ Detection System, Peroxidase/DAB+, Rabbit/Mouse was used for immunostaining. After being dried at room temperature, the slides were fixed with acetone for $10 \mathrm{~min}$. Then they were incubated for 5 min with Dual Endogenous Enzyme Block (Dako, Glostrup, Denmark). The sections were incubated with an appropriate antibody for 25 min for CD68, CD3, CD56 and neutrophil elastase (EBM11; F7.2.38; 123 C3 and NP57 Dako, Glostrup, Denmark). Afterwards incubation with Dako REAL ${ }^{\mathrm{TM}}$ EnVision ${ }^{\mathrm{TM}} / \mathrm{HRP}$, Rabbit/Mouse (ENV) for $25 \mathrm{~min}$ at room temperature was followed by a color reaction using Dako REAL ${ }^{\mathrm{TM}} \mathrm{DAB}+$ Chromogen for $3 \mathrm{~min}$. The slides were counterstained with Mayer's hematoxylin.

\section{Semi-quantitative analysis of immunohistochemical staining}

For quantitative evaluation 5 areas were chosen after scanning the tumor sections at low power 40x. These fields were analyzed at 200× magnification using Microlmage software (Olympus, Japan), counting total stained area.

\section{Statistical analysis}

A comparison was made for two groups with the Mann-Whitney $U$ test. Minimal level of significance was defined as $p<0.05$. 


\section{Results}

Pancreatic ductal adenocarcinoma (PDAC) tumors ranged from T1 to T4 (T1 $(n=3), \mathrm{T} 2(n=6), \mathrm{T} 3(n=25)$, and T4 $(n=2)$, N0 $(n=13), \mathrm{N} 1(n=23), \mathrm{MO}(n=33)$ and $M 1(n=3)$ stage. Also histological grade was evaluated: G1 $(n=4), G 2(n=16), G 3(n=16)$. Mean tumor size was $3.31 \mathrm{~cm}(1.7-5 \mathrm{~cm})$.
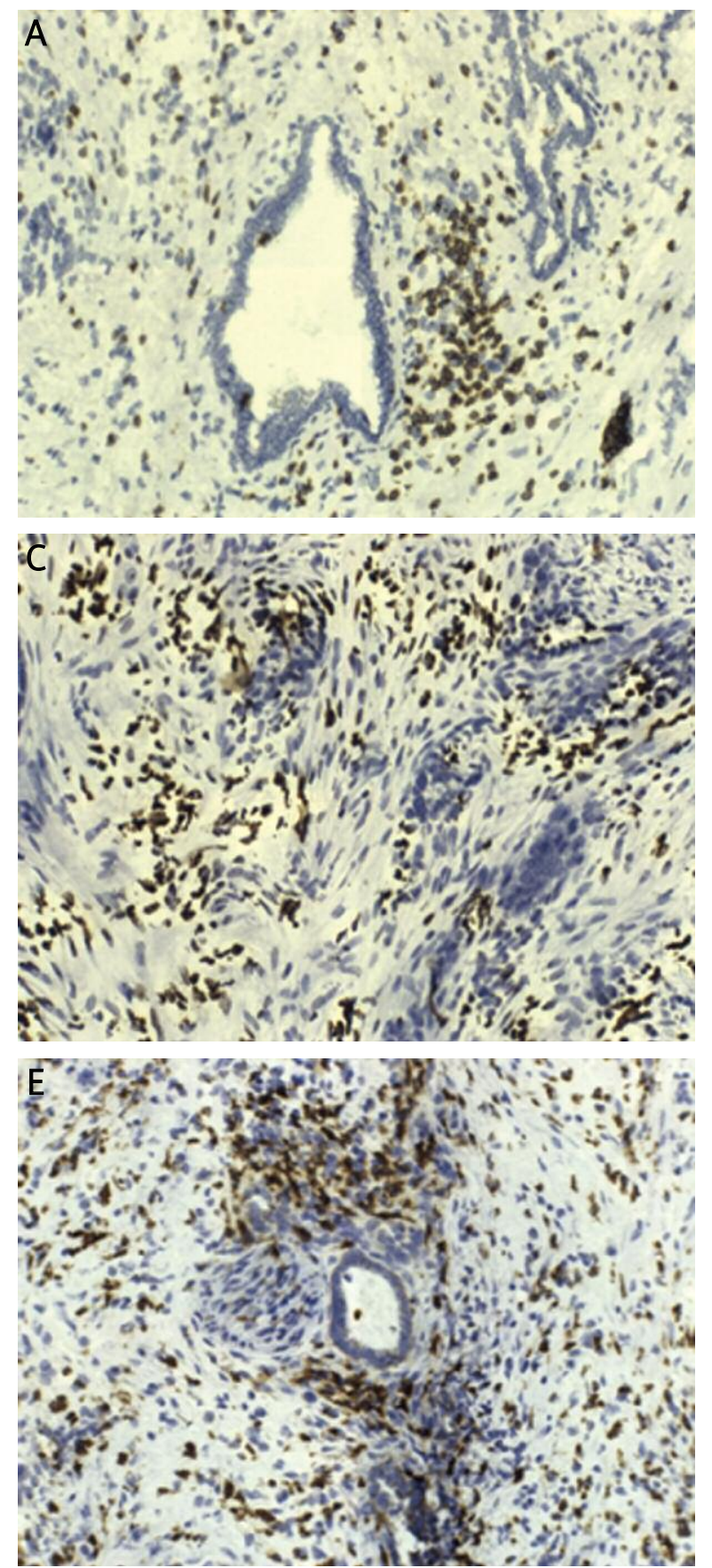

We found numerous lymphocyte and macrophage infiltrations in all studied tumor tissue. There was also strong expression of neutrophil elastase while no NK cell infiltration was observed. Inflammatory cells were present around neoplastic glands and also strongly around nerves infiltrated by cancer cells (Figure 1).
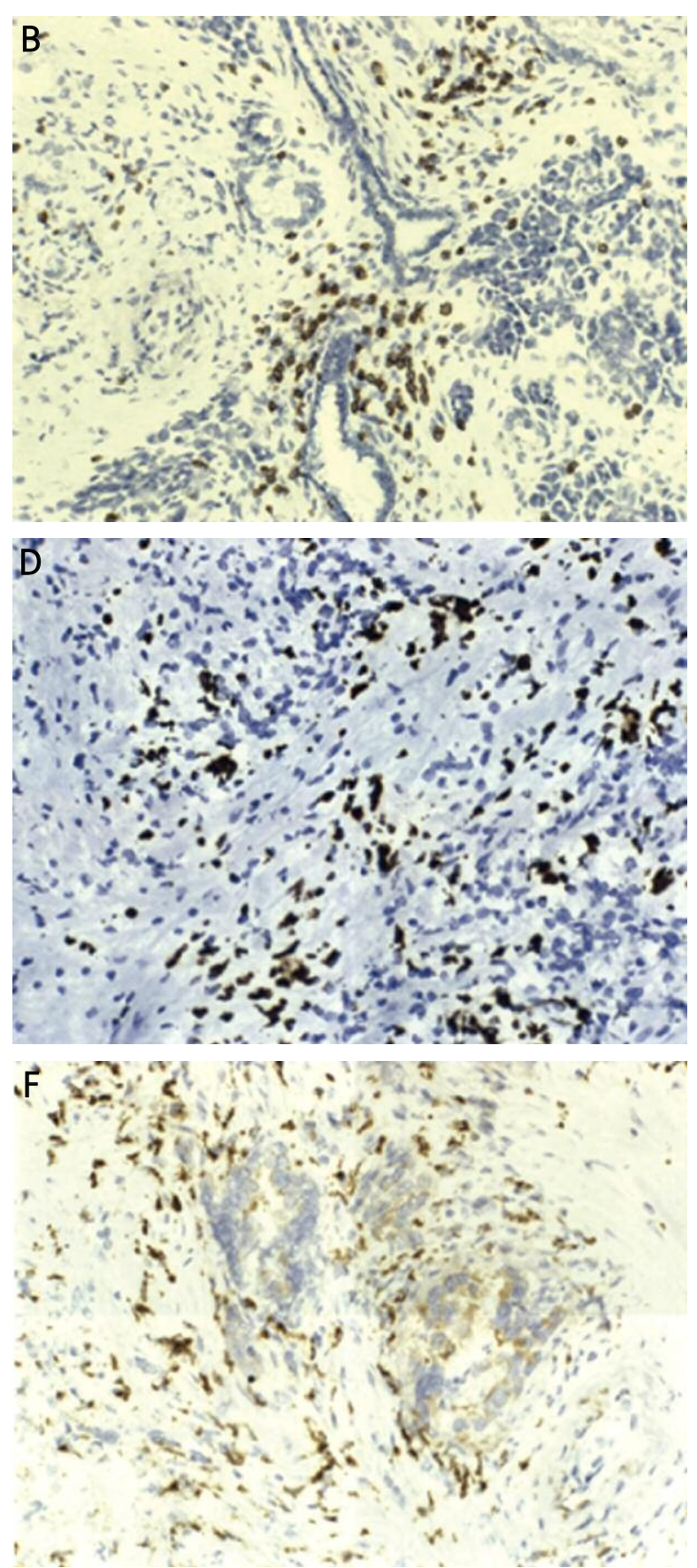

Fig. 1. Inflammatory infiltrates in pancreatic tumor tissue: A, B - lymphocytes, C, D - neutrophils, E, F- macrophages

Ryc. 1. Komórki nacieku zapalnego w tkance guza trzustki: A, B-limfocyty, C, D-neutrofile, E, F-makrofagi 


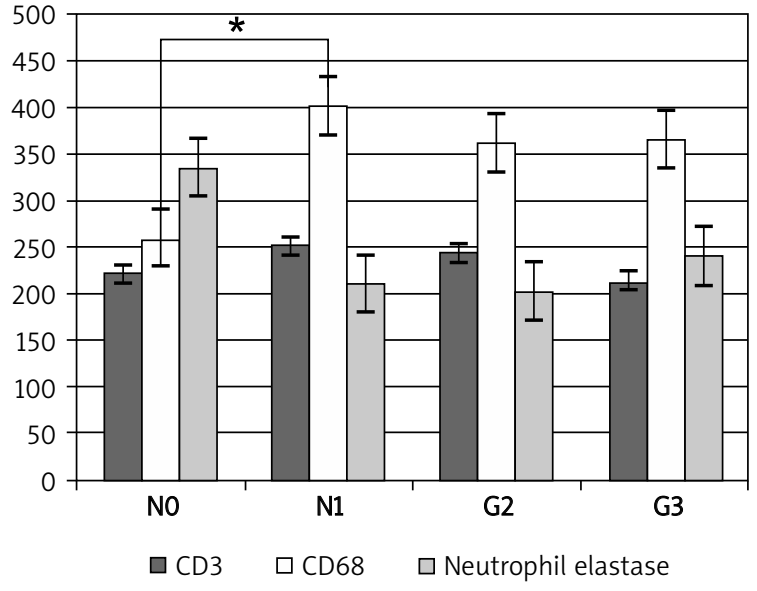

Fig. 2. Comparison of inflammatory infiltrates according to $\mathrm{N}$ stage and grade of differentiation Ryc. 2. Porównanie nacieków zapalnych według czynnika N i stopnia zróżnicowania guza

Comparing inflammatory infiltrates according to grade of differentiation we observed no differences between G2 $(n=16)$ and G3 $(n=16)$ grade (G1 was not included because of the small number of cases). According to $\mathrm{N}$ stage we found that the number of macrophages in tumor tissue was significantly higher in the group with metastases to lymph nodes (23) than in the No group (13) ( $p=0.0085)$. There was also a noticeable difference in expression of neutrophil elastase: it was higher in the N0 group than in N1 $(p=0.05)$ (Figure 2).

In $28 \%(n=10)$ of tumors vascular invasion was observed. In this group we noted that there was slightly more macrophages in tumor tissue. In contrast in tumors

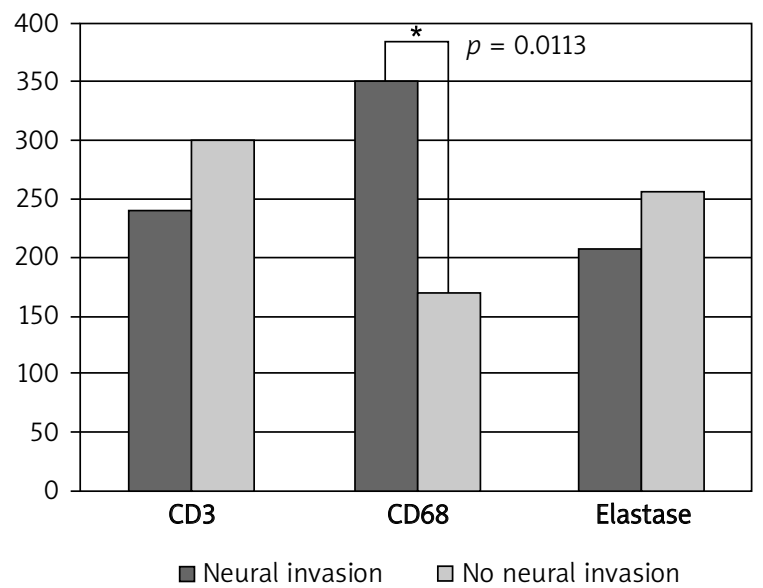

Fig. 4. Comparison of inflammatory infiltrates according to neural invasion incidence

Ryc. 4. Porównanie nacieków zapalnych według występowania naciekania nerwów

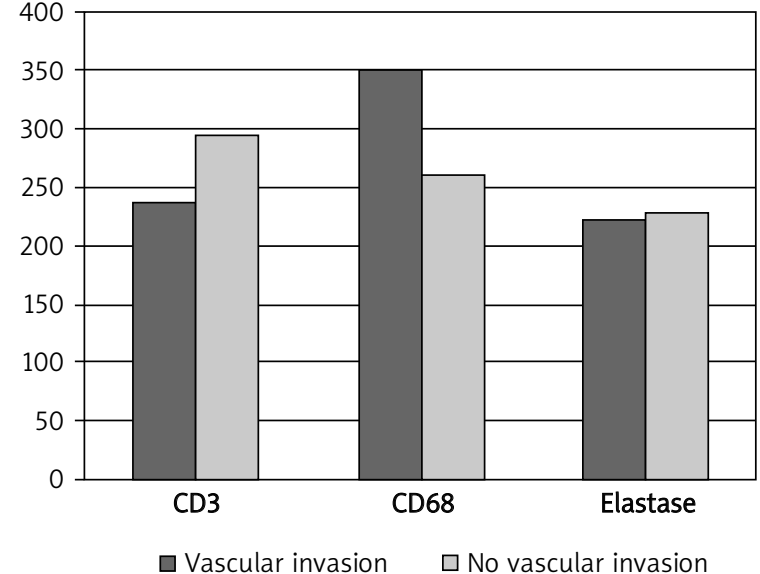

Fig. 3. Comparison of inflammatory infiltrates according to vascular invasion incidence Ryc. 3. Porównanie nacieków zapalnych wedtug występowania naciekania naczyń

without vascular invasion more $\mathrm{CD} 3+$ cells were observed (Figure 3).

In $70 \%(n=25)$ of studied tumors neural invasion was present. We found that this fact was related to significantly greater macrophage infiltrated ( $p=0.0113$ ). And similarly as in the case of vascular invasion, more distinct presence of lymphocyte infiltrates was related to lack of neural infiltration (Figure 4).

\section{Discussion}

This study has characterized the inflammatory cells within the tumor microenvironment of pancreatic cancer and identified how this influences tumor progression and metastases creation. Our observations indicate that in pancreatic adenocarcinoma immune cell infiltration affects the incidence of lymph node metastases and also neural and vascular invasion.

The immune response in cancer is essential as tumors are "wounds that do not heal" [9]. The tumor microenvironment influences infiltrating immune cells and changes their polarization towards pro-tumor phenotype. Earlier studies indicated that lymphocytes, macrophages and mast cells are a source of proangiogenic and prolymphangiogenic factors. The number of VEGF-A or VEGF-C positive inflammatory cells was correlated with the presence of lymph node metastases [10]. As they are also a source of proteases they rebuild tumor stroma and allow for creation of new vessels. They also react with adhesion molecules and facilitate cell detachment [11].

We have previously shown that in pancreatic cancer infiltrating immune cells are a source of matrix metalloproteinases [12]. Our present results indicate that nu- 
merous macrophage infiltrates are associated with lymph node metastases. The expression of CD68 was much higher in the N1 group than in NO. This is consistent with previous reports where tumor associated macrophages were shown to facilitate metastases [13]. On the other hand, Kurahara et al. found that in pancreatic cancer only a high number of M2-polarized macrophages resulted in high incidence of lymph node metastases [14].

We also found that infiltrating macrophages are related to neural invasion, which was also considered as a possible way of metastases. The molecular mechanism of this process has not been well recognized so far [15].

Another group of immune cells present in tumor tissue was neutrophils. Reid et al. studied tumor infiltration in pancreatic neoplasia. According to their criteria there was no neutrophil infiltration in adenocarcinoma [16]. We observed infiltration of neutrophils although they were not as numerous as macrophages and lymphocytes. We found that expression of elastase was higher in the NO group but it was not statistically significant. Previous research indicated that elastase takes part in tumor progression by activation of the PDGFR-PI3K pathway [8]. It might also point to N1 phenotype neutrophils, but it needs further study.

Interestingly, we found no NK cell infiltration. In other malignancies, like non-small cell lung carcinomas and colorectal cancer $[17,18]$, NK cells were present in tumor tissue and it was shown that they exhibit definite antitumor activity by direct action or by producing cytokines such as INF- $\gamma$ [19].

\section{Conclusions}

Pancreatic tumor is a place of complicated complex relationships and dependencies. There is no doubt that infiltrating tumor cells are a pivotal element of this microenvironment. In particular, macrophages take part in tumor progression and enable creation of metastases. Investigating infiltrating macrophages might be useful in evaluating the possibility of metastases occurrence.

\section{Acknowledgments}

This study was carried out with support from the Ministry of Science and Higher Education no. NN404/ 0693/33.

We would like to thank Prof. Anna NasierowskaGuttmejer and Dr Dorota Łącka for histopathological evaluation of tumors.

\section{References}

1. Raporty na podstawie danych Centrum Onkologii http://85. $128.14 .124 / \mathrm{krn} /$
2. Andrén-Sandberg A, Hedberg M, Winter K, Małecka-Panas E. Randomized trials in exocrine pancreatic cancer. Prz Gastroenterol 2011; 6: 85-96.

3. Talmadge JE, Donkor M, Scholar E. Inflammatory cell infiltration of tumors: Jekyll or Hyde. Cancer Metastasis Rev 2007; 26: 373-400.

4. Murray PJ, Wynn TA. Protective and pathogenic functions of macrophage subsets. Nat Rev Immunol 2011; 11: 723-37.

5. Mantovani A, Cassatella MA, Costantini C, Jaillon S. Neutrophils in the activation and regulation of innate and adaptive immunity. Nat Rev Immunol 2011; 11: 519-31.

6. Fridlender ZG, Sun J, Kim S, et al. Polarization of tumor-associated neutrophil phenotype by TGF-b: "N1" versus "N2" TAN. Cancer Cell 2009; 16: 183-94.

7. Yamashita J, Ogawa M, Shirakusa T. Free-form neutrophil elastase is an independent marker predicting recurrence in primary breast cancer. J Leukoc Biol 1995; 57: 375-8.

8. Houghton AM, Rzymkiewicz DM, Ji H, et al. Neutrophil elastase-mediated degradation of IRS-1 accelerates lung tumor growth. Nature Med 2010; 16: 219-23.

9. Bissell MJ, Radisky D. Putting tumours in context. Nat Rev Cancer 2001; 1: 46-54.

10. Esposito I, Menicagli M, Funel N, et al. Inflammatory cells contribute to the generation of an angiogenic phenotype in pancreatic ductal adenocarcinoma. J Clin Pathol 2004; 57: 630-6.

11. Egeblad M, Werb Z. New functions for the matrix metalloproteinases in cancer progression. Nat Rev Cancer 2002; 2: 161-74.

12. Durlik M, Gardian K. Metalloproteinase 2 and 9 activity in the development of pancreatic cancer. Pol Przegl Chir 2012; 84: 377-82.

13. Pollard JW. Tumor-educated macrophages promote tumor progression and metastasis. Nat Rev Cancer 2004; 4: 71-8.

14. Kurahara H, Takao S, Maemura K, et al. M2-polarized tumorassociated macrophage infiltration of regional lymph nodes is associated with nodal lymphangiogenesis and occult nodal involvement in pancreatic cancer. Pancreas 2012 Jun 13 [Epub ahead of print].

15. Demir IE, Friess H, Ceyhan GO. Nerve-cancer interactions in the stromal biology of pancreatic cancer. Front Physiol 2012; 3: 97.

16. Reid MD, Basturk O, Thirabanjasak D, et al. Tumor-infiltrating neutrophils in pancreatic neoplasia. Mod Pathol 2011; 24: 1612-9.

17. Platonova S, Cherfils-Vicini J, Damotte D, et al. Profound coordinated alterations of intratumoral NK cell phenotype and function in lung carcinoma. Cancer Res 2011; 71: 5412-22.

18. Halama N, Braun M, Kahlert C, et al. Natural killer cells are scarce in colorectal carcinoma tissue despite high levels of chemokines and cytokines. Clin Cancer Res 2011; 17: 678-89.

19. Ménard C, Blay JY, Borg C, et al. Natural killer cell IFN-gamma levels predict long-term survival with imatinib mesylate therapy in gastrointestinal stromal tumor-bearing patients. Cancer Res 2009; 69: 3563-9. 